\title{
Impact of 2nd wave of COVID-19-related lockdown on coastal water quality at Diu, western coast of India and role of total alkalinity on bacterial loads
}

\author{
Atanu Kumar Panja ${ }^{1}$. Sonpal Vasavdutta ${ }^{1}$ Tarini Prasad Sahoo ${ }^{1}$ - Ambika H. Shinde ${ }^{1,3}$. \\ Ravikumar Bhagawan Thorat $^{1,3} \cdot$ Shruti Chatterjee $^{2}$. Sanak Ray ${ }^{1,3} \cdot$ Anil Kumar Madhava $^{1,3} \cdot$ Soumya Haldar $^{1,3}$ (1)
}

Received: 11 November 2021 / Accepted: 7 February 2022 / Published online: 14 February 2022

(c) The Author(s), under exclusive licence to Springer-Verlag GmbH Germany, part of Springer Nature 2022

\begin{abstract}
A detailed coastal water monitoring near Diu coast, western part of India was performed from October, 2020 to May, 2021 covering the 2nd lockdown time. Average monthly fluctuation from 7 different sampling stations of total 9 physico-chemical parameters such as $\mathrm{pH}$, salinity, turbidity, nitrite $\left(\mathrm{NO}_{2}\right)$, nitrate $\left(\mathrm{NO}_{3}\right)$, ammonia $\left(\mathrm{NH}_{3}\right)$, phosphate $\left(\mathrm{PO}_{4}\right)$, total alkalinity and silicate were recorded. Initially, Mann-Kendall trend test for all the 9 parameters showed non-zero trend, which may be either linear or non-linear. During 2nd lockdown period, there was a fluctuation of value for parameters like $\mathrm{pH}$, salinity, nitrate, nitrite and phosphate. Average total bacterial count and differential bacterial count also gradually decreased from March, 2021 sampling. Principal component analysis (PCA) plot covering all the physico-chemical parameters as well as the differential bacterial count showed a distinct cluster of all bacterial count with total alkalinity value. Subsequently, mathematical equation was formulated between total alkalinity value and all differential bacterial count. Upto our knowledge, this is the first report where mathematical equation was formulated to obtain value of different bacterial load based on the derived total alkalinity value of the coastal water samples near Diu, India.
\end{abstract}

Keywords Alkalinity · Bacterial loads · COVID-19 $\cdot$ Diu $\cdot$ Fluctuation $\cdot$ Lockdown $\cdot$ Mann-Kendall trend

\section{Introduction}

Diu is one of the popular tourist destination and also it is considered as one of the major fish landing centre and fishing harbour. Ministry of Tourism, Government of India data showed that in the year 2014, a total of 1.01 million domestic and 0.003 million foreign tourists visited Diu (NIP, 2020)

Responsible Editor: Philippe Garrigues.

Soumya Haldar

shaldar@csmcri.res.in

1 Analytical and Environmental Science Division \& Centralized Instrument Facility, CSIR-Central Salt \& Marine Chemicals Research Institute, Bhavnagar 364 002, Gujarat, India

2 Applied Phycology and Biotechnology Division, CSIR-Central Salt \& Marine Chemicals Research Institute, Bhavnagar 364 002, Gujarat, India

3 Academy of Scientific and Innovative Research (AcSIR), Ghaziabad 201002, India and the number has increased further. Another important source of livelihood at Diu is marine fishery and in fishery sector, there are more than 100 big mechanized trawlers, around 50 numbers of mechanized fibre-reinforced plastic (FRP) and 250 motorized FRP operated from this fishing harbour regularly (Fisheries Department, Diu. 2013). Diu coast length is around $27 \mathrm{~km}$ of which number of landing centre are 12. A total of 3100 fishermen families are involved in fishing activity, majority of which is coastal or deep sea fishing (Department of Fisheries. 2019).

Similar to other part of the country, due to COVID-19 lockdown, there was a total restriction in tourists entry at Diu from April 2020 onwards, which was eased at low pace from September, 2020 (1st wave). Furthermore, there was another restriction during March-May, 2021 due to 2nd wave of COVID-19 in the country. Total marine catch in Diu increased from 27,000 tons in 2018-2019 to 31,800 tons in 2019-2020 (Fisheries Deapartment, Diu. 2013). However, there is a drastic reduction in the year 2020-2021 due to pandemic-related reduction in fishing activities (personal communication, data not available so 
far). Recently, our group has reported the self-replenishing capacity of Alang ship recycling yard (the world largest ship recycling yard), area located $30 \mathrm{~km}$ away from Diu, and it was clearly shown that due to cessation of anthropogenic activities, during April-May, 2020; there is a considerable reduction in different physico-chemical parameters in both coastal water and sediment samples as well as in the ambient air (Chanchpara et al. 2021). In another recent study, it has already been reported that different anthropogenic activities are the source of water pollution (Lotliker et al. 2021). Furthermore, the coastal water of India in the vicinity of major cities are strongly influenced by the anthropogenic discharges (Zingde and Govindan. 2000; Verlecar et al. 2006; Khatri and Tyagi. 2015; Gopal et al. 2018). However, there is no such study in comparatively pristine environment like Diu where anthropogenic impacts are mostly depend on the tourist inflow and fishing-related activities. CSIR-CSMCRI has initiated a project to monitor the monthly physico-chemical and biological parameters of Diu coast from October, 2020.

Based on all the data, the objective of the present work is (1) to understand the impact of 2nd lockdown (March-May, 2021) with respect to different physico-chemical as well as biological parameters including bacterial distribution in comparison to the previous months when normal activities prevailed (2) to identify the physico-chemical factor which can regulate bacterial load and (3) to develop an algorithm to co-relate between different bacterial counts and the identified physico-chemical parameter. Upto our understanding, this is the first report where attempt is made to correlate specific physico-chemical parameter and bacterial load based on mathematical equation. This work will definitely help to understand the coastal health of other area when selected physico-chemical parameters are available. This study will also help to improve the coastal management by restricting the release of selected parameters which indirectly reduce the load of the pathogenic bacteria.

\section{Materials and methods}

\section{Selection of sampling stations and collection of samples}

Sampling sites were selected in the area which is $3-10 \mathrm{~km}$ away from the Diu coast. Station 1 (S1) was selected for establishment of buoy which will collect selective physicochemical data online in the future. This point is away from the regular vessel movement and all other stations were selected based on their location having an approximate depth of 15 to $20 \mathrm{~m}$ representing the coastal and near shore sampling location. Emphasis was given to select station where impact of near shore anthropogenic activity can be reflected. A total of 7 sampling stations were selected and monthly water samples were collected from all the stations as illustrated in Fig. 1 and sampling was done in the morning from 8 to $12 \mathrm{~h}$. All the sensitive parameters were analysed within 3-6 h after collection of the samples. For microbiology, after collection, all the samples were stored in cool pack and microbiological platting were made within $6 \mathrm{~h}$ at field laboratory (Haldar et al. 2011). A total of 6-month sampling programme were carried out covering the same stations. The sampling months were October, 2020; January, February, March, April and May, 2021.

\section{Analytical method for physico-chemical parameters}

The analysis of different physico-chemical parameters of seawater samples, i.e. $\mathrm{pH}$, salinity, turbidity, nitrite $\left(\mathrm{NO}_{2}{ }^{-}\right)$, nitrate $\left(\mathrm{NO}_{3}{ }^{-}\right)$, ammonia $\left(\mathrm{NH}_{3}\right)$, phosphate $\left(\mathrm{PO}_{4}{ }^{-}\right)$, total
Fig. 1 Map showing the selected sampling locations

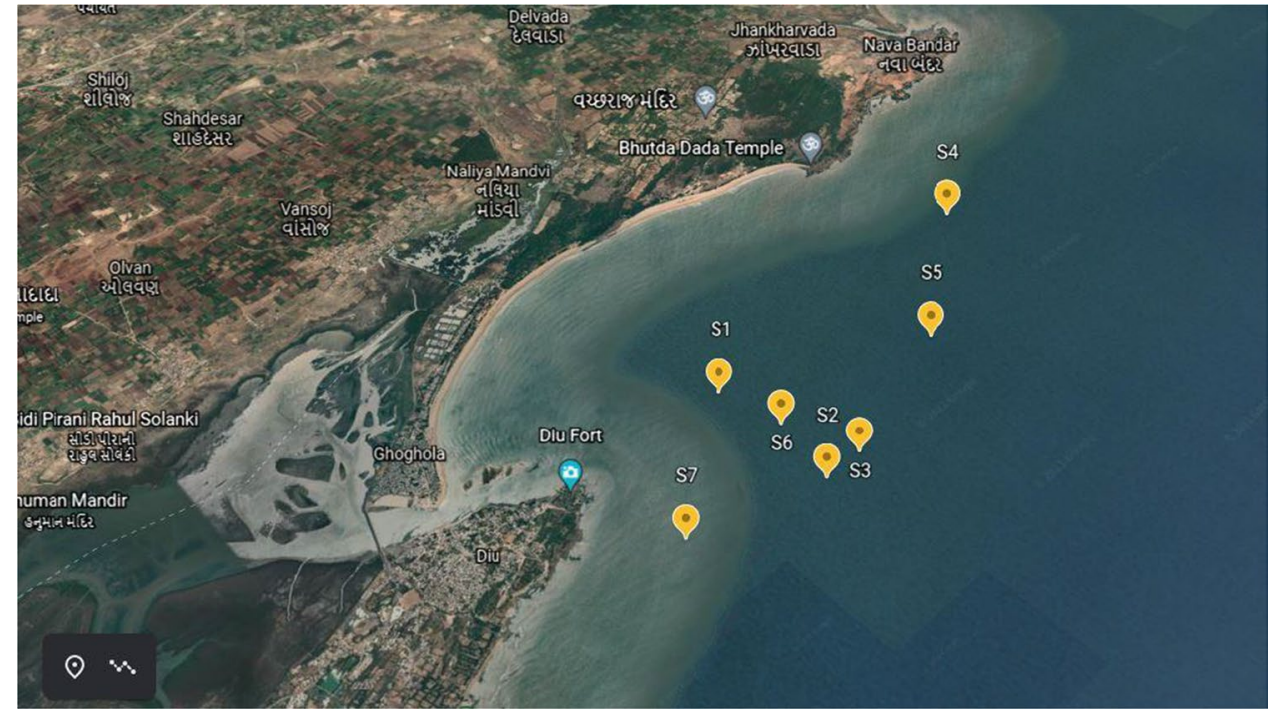


alkalinity and silicate were done as per our previous paper (Haldar et al. 2014) following the detailed methods described in APHA. (2017). In detail, pH was measured by $\mathrm{pH}$ pen (Eutech), salinity was measured by hand held device (ATAGO Master refractometer) and turbidity was measured by turbidometer TN-100 (Eutech). Calibration was made before all measurements and all samples were measured at the site just after collection. The nutrient parameters such as nitrite, nitrate, ammonia and inorganic phosphate were analysed spectrophotometrically on an UV-Vis spectrophotometer (Shimadzu-1201). Nitrite $\left(\mathrm{NO}_{2}{ }^{-}\right)$in the sample was allowed to react with sulphanilamide in acidic solution. The resulting diazo compound was reacted with $\mathrm{N}$-(1-naphthyl)ethylenediamine to form a highly coloured azo-dye and the absorbance was measured at $543 \mathrm{~nm}$. Nitrate $\left(\mathrm{NO}_{3}{ }^{-}\right)$was estimated as nitrite as above after its reduction by passing the sample through a column packed with amalgamated cadmium. Ammonia $\left(\mathrm{NH}_{4}\right)$ in seawater was allowed to react with hypochlorite in moderately alkaline solution to form monochloramine, which in presence of phenol and excess of hypochlorite formed indophenol blue complex which was measured at $630 \mathrm{~nm}$. Inorganic phosphate $\left(\mathrm{PO}_{4}\right)$ was determined by adding acidified molybdate reagent to yield phosphor-molybdate complex which was then reduced with ascorbic acid to form a highly coloured blue compound which was measured at $882 \mathrm{~nm}$.

\section{Bacteriological analysis}

Selective media were used for isolation of different bacterial species from coastal water and all the media were purchased from HiMedia, India. Thiosulfate citrate bile salts sucrose (TCBS) agar was used for culture of pathogenic Vibrio species, MacConkey and MacConkey Sorbitol agar (Mac-S) were used for isolation of Escherichia coli, Aeromonas isolation media (AIM) were used for isolation of Aeromonas hydrophila, xylose-lysine deoxycholate (XLD) agar was used for isolation of Salmonella spp., Pseudomonas isolation agar (PIM) was used for isolation of Pseudomonas sp. Zobell Marine agar (ZMA) was used for isolation of total heterotrophic bacteria. The detailed culture method was adopted from our previous study (Patel et al. 2014). In detail, $100 \mu \mathrm{L}$ of water samples were inoculated in each plate and incubated at $37{ }^{\circ} \mathrm{C}$ for $48 \mathrm{~h}$. Subsequently, colonies were counted and the bacterial load was expressed in CFU/mL after multiplying with the dilution factor.

\section{Statistical analysis}

The statistical analysis of the obtained data was performed and for this purpose, the primary data was rearranged for the ease of analysis. As the sampling points were not very far from each other $(0.5-1.0 \mathrm{~km}$ apart $)$, there were small variations recorded from the one site to another site. Henceforth, the mean value for each parameter for one-time monthly sampling covering all the stations were considered. Initially, Mann-Kendall trend test for all the 9 parameters were performed to understand the possible trend in 6 months' data obtained from the sites. After Mann-Kendall test (non-zero trend), which may either be linear or nonlinear, Mann-Kendall test statistic ("trend package") is calculated according to:

$S=\sum_{k=1}^{n-1} \sum_{j=k+1}^{n} \operatorname{sgn}\left(x_{j}-x_{k}\right)$

where $\mathrm{S}$ is the trend value, $\mathrm{n}$ is the number of experimental inputs, sgn is the signum function, $x_{j}$ and $x_{k}$ are $\mathrm{j}^{\text {th }}$ and $\mathrm{k}^{\text {th }}$ variables, respectively. Thereafter, a trend graph was plotted based on the 6-month data obtained from the different sites. Mann-Kendall trend test was performed using 'trend' package of ' $R$ ' statistical software while the graphical plots were generated using MINITAB software.

\section{Results}

\section{Water health of Diu coast during lockdown}

A detailed monthly variation in different water quality parameters were analysed and interpreted using Mann-Kendall trend test. Thereafter, a trend graph was plotted based on the 6-month data obtained from the different sites. Fluctuations during March, 2021 to May, 2021 were noted when the activity was minimum due to 2nd phase of COVID-19 lockdown. $\mathrm{pH}$ of the coastal water is one of the sensitive parameters and overall saline water has an alkaline $\mathrm{pH}$. The $\mathrm{pH}$ values observed in this study varied between 7.5 and 8.3, and for which the $p$-value from the trend test is comparatively low (0.08517) which signifies that the actual value followed predicted trend line as shown in the Fig. 2a. Salinity values varied between 30-33 ppt as shown in Fig. 2b where both the trend lines are comparable thus there is a drop of salinity value during April-month sampling and this phenomena is due to no anthropogenic activity. It is observed that there is no particular trend in the monthly salinity data which was evidenced by the greater $p$-value, 0.8404 .

After 1st lockdown, sampling started from October, 2020 and there was a gradual increase in the value of turbidity upto March, 2021 as shown in the Fig. 3a. Turbidity value varied between 2.9 and 5.6 NTU. The $p$-value for the trend test of turbidity was observed as 0.0267 , a significant positive trend was found in the datasets. Furthermore, when the 2nd phase lockdown initiated, a flat trend line was observed in all the stations and this may be due to the fact that reduction of vehicular movement do not have significant impact 

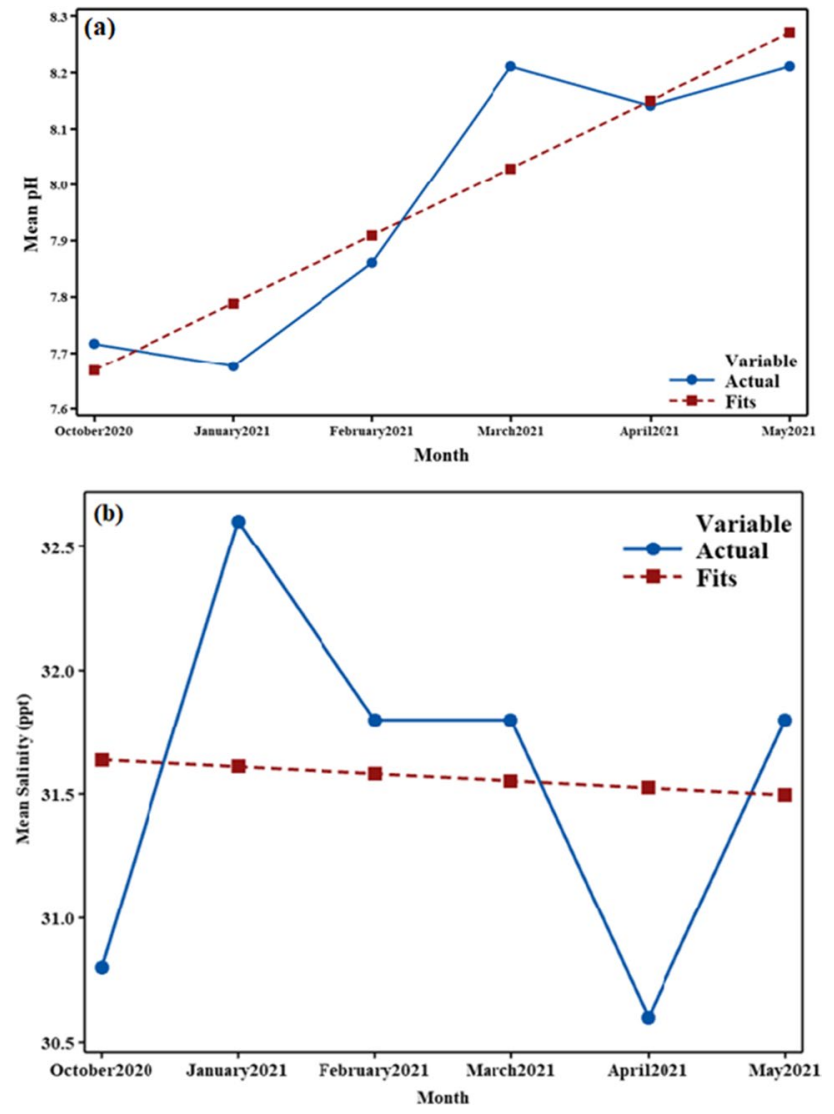

Fig. 2 Trend analysis plot for the monthly fluctuation of $\mathbf{a} \mathbf{p H}$ and $\mathbf{b}$ salinity in all stations

on the turbidity value. However, an overall upward trend was observed in the total study period.

In case of total alkalinity, when complete lockdown was maintained due to 2nd wave of COVID-19 (April, 2021), a sudden surge of total alkalinity value was observed as in the Fig. 3b. Overall, the total alkalinity value varied between 10 and $30 \mathrm{mg} / \mathrm{L}$. The obtained $p$-value for the trend test of the total alkalinity is 0.8483 , indicating that there is no regular trend in the monthly total alkalinity data. This variation may be due to sharp increase in value during the month of April, 2021.

There were no regular trends observed for nitrite and nitrate concentrations during this period. The value varied between 0.08 and $14.63 \mathrm{mg} / \mathrm{L}$. During October sampling, high value of $\mathrm{NO}_{2}^{-}$was recorded in all the stations, which decreased substantially in the following month samples. There was a decreasing trend of $\mathrm{NH}_{4}-\mathrm{N}$ value which varied from 0.02 to $1.19 \mathrm{mg} / \mathrm{L}$. The obtained $p$-value for nitrate, nitrite and ammonia were $0.08517,0.8483$ and 0.08517 , respectively.

Overall, the silicate value of different water samples with different sampling period varied between 2.33 and
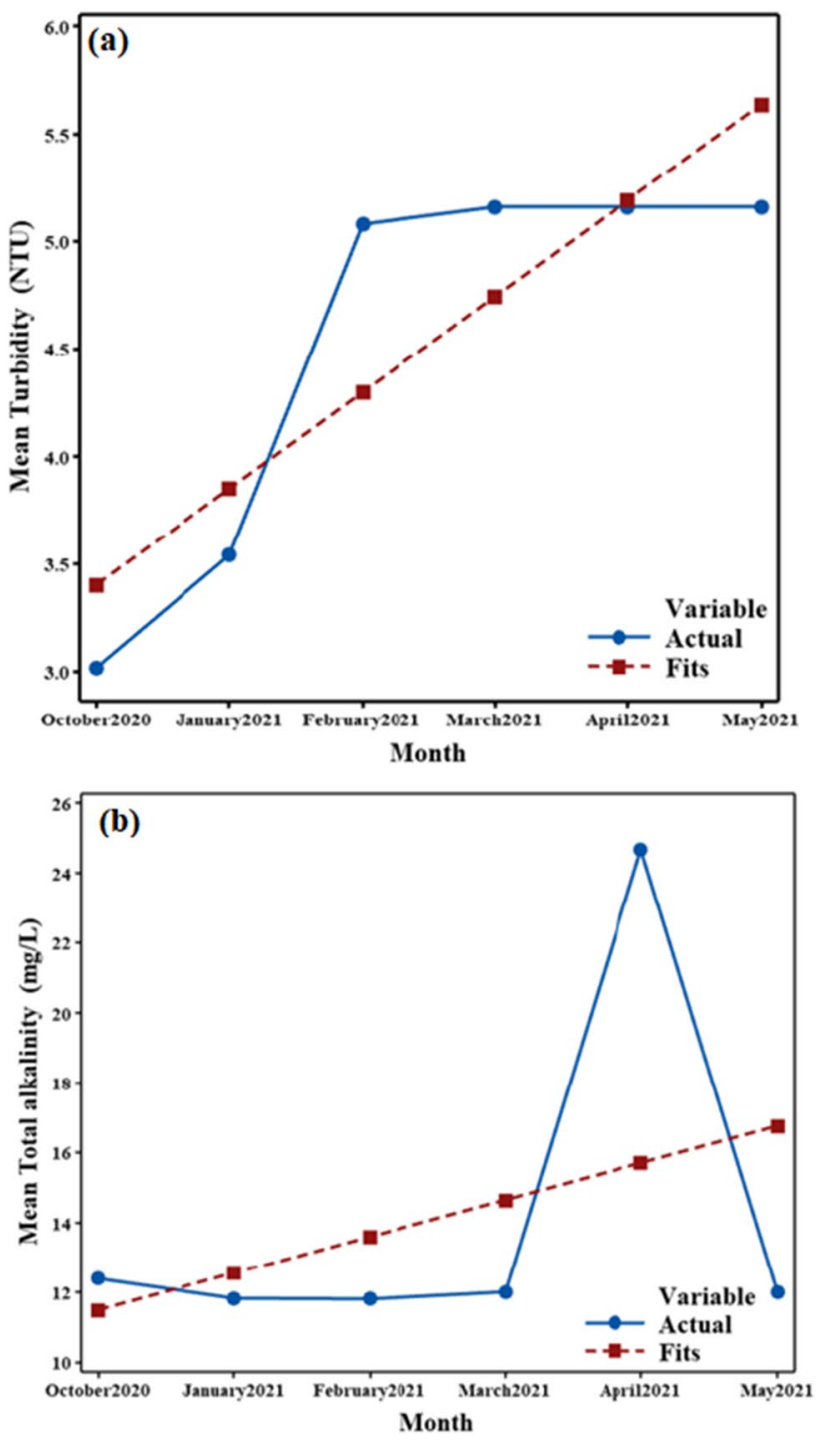

Fig. 3 Trend analysis plot for the monthly fluctuation of a turbidity and $\mathbf{b}$ total alkalinity in all stations

$15.63 \mathrm{mg} / \mathrm{L}$. Silicate values were high at the initial stage (Fig. 4a), then it reduced sharply and maintained an almost straight line during subsequent months.

Imbalance in nitrate and phosphate ratio causes eutrophication and in the present study, there was no significant trend of average phosphate concentration because the $p$-value is 0.8483 . The phosphate concentration was near minimal during April, 2021 sampling as illustrated in Fig. 4b. The oveall $\mathrm{PO}_{4}{ }^{-}$value varied between 0.01 and $0.6 \mathrm{mg} / \mathrm{L}$; as phosphate has a huge impact on primary productivity of coastal water, this outcome predicts that the primary productivity was low during the 2 nd phase lockdown. 

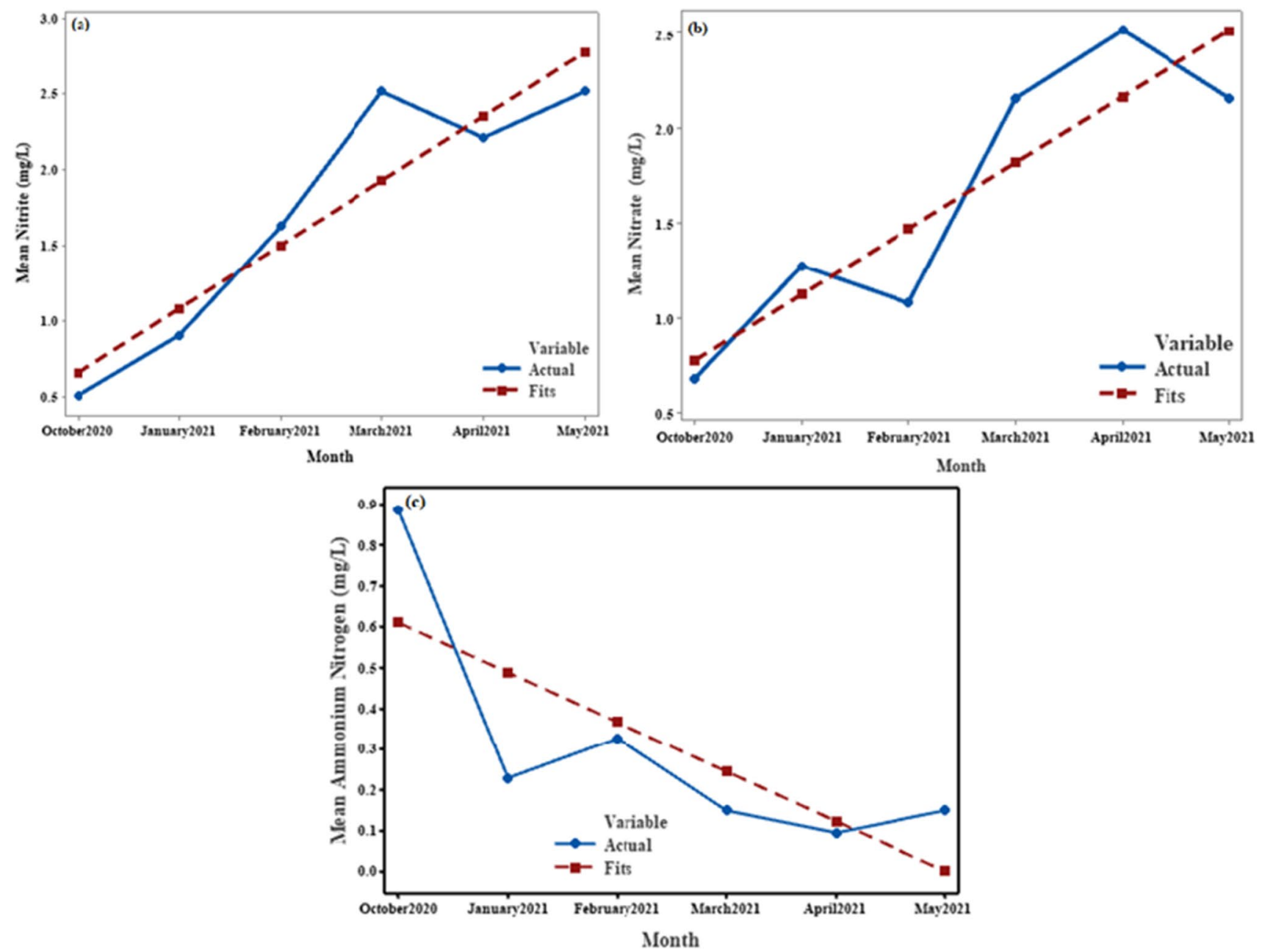

Fig. 4 Trend analysis plot for the monthly fluctuation of $\mathbf{a}$ nitrite, $\mathbf{b}$ nitrate and $\mathbf{c}$ ammonium nitrogen in all stations

\section{Microbiology data}

In the case of $E$. coli, during October sampling, the value was varied between 20 and $260 \mathrm{CFU} / \mathrm{mL}$; however, in the subsequent months, it reduced drastically and in majority of the samples, E. coli was not detected. Similar trend was observed in the case of Aeromonas sp., which was varied between 20 and $90 \mathrm{CFU} / \mathrm{mL}$ during October sampling and again appear during April samples (varied between 10 and $790 \mathrm{CFU} / \mathrm{mL}$ ). Salmonella sp. was also recorded in lesser number during April, 21 sampling (20 to $80 \mathrm{CFU} /$ $\mathrm{mL})$. Streptococcus sp. was only detected in S2 station (110 CFU/mL) during initial sampling (October and February) which was completely undecetable in all other stations throughout the study period. Pseudomonas sp. was detected throughout the sampling periods from majority of the stations. The number varied between 10 and $700 \mathrm{CFU} /$ mL Table 1.

\section{Bacterial load with respect to selected physico-chemical parameter of the coastal water}

Among the different physico-chemical parameters tested, there was a sudden fluctuation of alkalinity values in the 6 -month sampling data. The outcome of PCA revealed that the total alkalinity value formed a close cluster with all the bacterial load value (Fig. 5) while the other physico-chemical parameters formed separate clusters. Alkalinity has a long term impact on different physico-chemical parameters and also the PCA analysis shows that the different bacterial load has a relation (formed same cluster in PCA plot) with total alkalinity value. Therefore, an attempt was further made to derive a mathematical relationship (regression analysis) between obtained total alkalinity value and the differential bacterial loads. It was observed that total bacterial count derived by 
Table 1 Statistical coorelations from the trend analysis for the parameters

\begin{tabular}{lcccll}
\hline Parameters & Equation & MAPE & MSD & MAD & $p$-value \\
\hline $\mathrm{pH}$ & $Y t=7.547+0.1203 \times \mathrm{t}$ & 0.957837 & 0.008950 & 0.076451 & 0.08517 \\
Turbidity (NTU) & $Y t=2.956+0.447 \times \mathrm{t}$ & 9.12586 & 0.20973 & 0.40000 & 0.02677 \\
Total alkalinity (mg/L) & $Y t=10.45+1.05 \times \mathrm{t}$ & 20.9923 & 19.0209 & 3.2867 & 0.8483 \\
Salinity (ppt) & $Y t=31.667-0.029 \times \mathrm{t}$ & 1.86737 & 0.45651 & 0.58730 & 0.8404 \\
Nitrate nitrogen (mg/L) & $Y t=0.428+0.3469 \times \mathrm{t}$ & 17.9825 & 0.0911 & 0.2797 & 0.8483 \\
Phosphate (mg/L) & $Y t=0.404-0.0457 \times \mathrm{t}$ & 146.385 & 0.029 & 0.163 & 0.8483 \\
Ammonium nitrogen (mg/L) & $Y t=0.734-0.1221 \times \mathrm{t}$ & 58.4933 & 0.0297 & 0.1416 & 0.08517 \\
Silicate $(\mathrm{mg} / \mathrm{L})$ & $Y t=9.43-1.493 \times \mathrm{t}$ & 64.8715 & 7.2636 & 2.2934 & 0.2423 \\
Nitrite nitrogen $(\mathrm{mg} / \mathrm{L})$ & $Y t=0.233+0.4229 \times \mathrm{t}$ & 15.8708 & 0.0830 & 0.2380 & 0.08517 \\
\hline
\end{tabular}

platting in ZMA medium and other differential bacterial counts such as TCBS, Mac Conkey-S, AIM, XLD and PIM showed the relationship with total alkalinity by the equations mentioned in the Table 2 . Furthermore, these equations were validated with the obtained data.
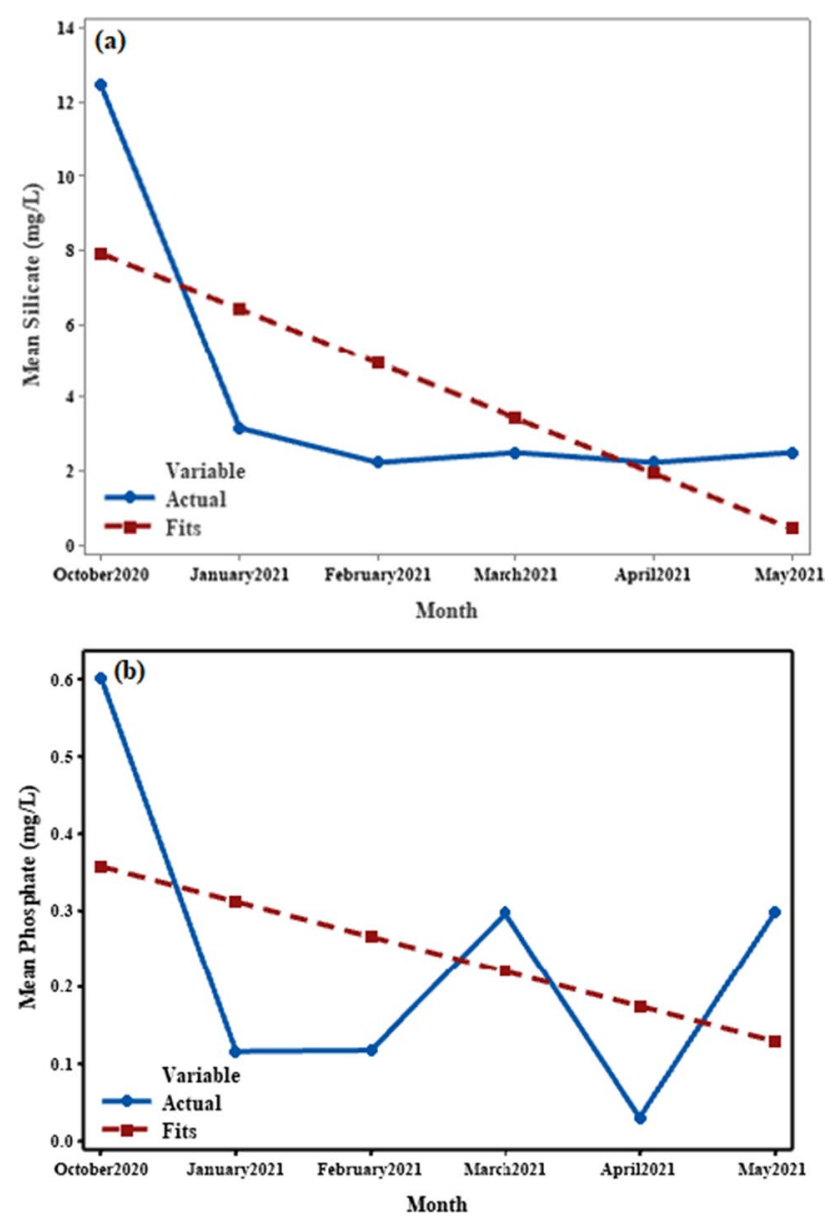

Fig. 5 Trend analysis plot for the monthly fluctuation of a silicate and b phosphate in all stations

\section{Discussion}

\section{Water health status of Diu coast during lockdown}

It is reported that due to anthropogenic activities including vehicular movement, there is an increase in atmospheric carbon dioxide $\left(\mathrm{CO}_{2}\right)$ concentrations which finally sink to ocean resulting ocean acidification and $\mathrm{pH}$ reduction (Gao et al. 2019). The complete halt of vehicular movement as well as fishing boat operations during the 2nd phase of COVID-19 lockdown would have resulted in the slight reduction of $\mathrm{pH}$.

The total difference in salinity value was 3 ppt only, therefore, it has no significant effect on the overall environment. As reverse osmosis-based desalination, plants are getting popularized throughout coastal India, one of the major drawback is the release of reject water discharged back to the coastal water which has much higher salinity than normal seawater (Ahuja et al. 2014; Hussain et al. 2019). Due to complete lockdown, the desalination plants were non-operational, which might be the reason for the reduction of overall salinity during the 2nd phase lockdown sampling.

There was a sudden increase in total alkalinity value in all the station during April, 21 sampling and the reason for sudden increase in total alkalinity was not understood completely. However, the high alkalinity value helped to stabilize the marine water $\mathrm{pH}$. During May, 2021, again, the value came down to the normal level. Sewage discharges both treated and partially treated as well as other domestic effluents are the major cause for the variation of nutrient concentration in the coastal area (Peters and Meybeck. 2000; Buck et al. 2004; Zhang et al. 2009; Hussain and Badola. 2008; Uddin and Jeong. 2021). However, during the 2nd phase lockdown (March to May, 2021) an interesting relation was observed between $\mathrm{NO}_{3}{ }^{-}, \mathrm{NO}_{2}{ }^{-}$and $\mathrm{NH}_{4}-\mathrm{N}$ concentrations as illustrated in the Fig. $6 \mathrm{a}-\mathrm{c}$. Nitrate value was maximum during April (varied between 1.63 and $3.16 \mathrm{mg} / \mathrm{L}$ ) and May, 2021 (varied between 1.09 to $3.3 \mathrm{mg} / \mathrm{L}$ ) in comparison with nitrite and ammonia values. This might be due to the activity of de-nitrifying and ammonifying bacteria in the water which generally convert nitrate to nitrite to ammonia (Zakem 
Table 2 Mathematical relationship between the bacterial mean value and the total alkalinity

\begin{tabular}{|c|c|c|c|c|}
\hline $\begin{array}{l}\text { Media used for } \\
\text { culture }\end{array}$ & Type of bacterial cultures & Regression equation & Correlation value & $p$-value \\
\hline ZMA & Total bacteria counts & ZMA mean $=-728+1138.8 \times$ total alkalinity & 0.9643581 & 0.001883 \\
\hline TCBS & Vibrio load & TCBS mean $=-114.12+10.044 \times$ total alkalinity & 0.9968413 & $1.495 \mathrm{e}-05$ \\
\hline Mac. S & Escherichia coli & Mac.S mean $=-118.04+10.13 \times$ total alkalinity & 0.9983208 & $4.227 \mathrm{e}-06$ \\
\hline AIM & Aeromonas hydrophila & AIM mean $=-114.12+10.044 \times$ total alkalinity & 0.9948055 & $4.04 \mathrm{e}-05$ \\
\hline XLD & Salmonella spp. & $\mathrm{XLD}$ mean $=-12.63+1.189 \times$ total alkalinity & 0.9704215 & 0.001299 \\
\hline PIM & Pseudomonas sp. & PIM mean $=-25+10.8 \times$ total alkalinity & 0.5171161 & 0.2935 \\
\hline
\end{tabular}

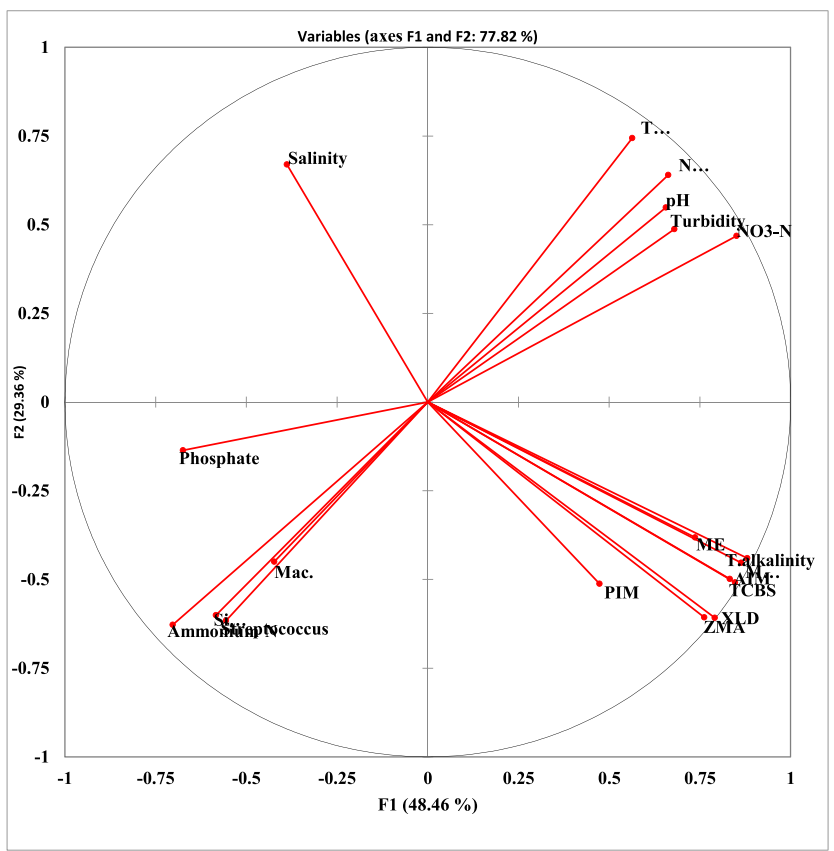

Fig. 6 PCA plot of bacterial load with physico-chemical parameters

et al. 2018). There might be other reactions such as direct reduction from nitrate to ammonium, a process known as dissimilatory nitrate reduction to ammonium or DNRA (An and Gardner. 2002). It can be concluded that the microbial activity was strong during this 2 nd phase lockdown period.

It is already reported that silicate can enter to the coastal water through river discharge, sub-marine ground water discharge and to a small extent through coastal upwelling (Kumar. 2021). Also, silicate to nitrate ratio has a significant impact on the phytoplankton community in the coastal waters. Furthermore, it was also hypothesized that change in silicate to nitrate ratios were the possible reason for the occurrence of frequent harmful algal bloom (HABs-dinoflagellates) in the coastal water of Arabian sea (Kumar. 2021). However, no such occurrence was observed during March to May, 2021 in the study area and this was established by high $p$-value $(0.2423)$ signifying that the fluctuations of monthly observed value of silicate may not support the formation of HABs.

\section{Microbiology of Diu coastal water}

It was already reported that coastal water is the hotspot for the reservoir of different pathogenic bacteria (Shinde et al. 2020). Furthermore, cases of water borne diseases are directly related to their primary proximity to the coast (Batabyal et al. 2014). Therefore, monitoring the different pathogenic bacterial load is eminent to understand the coastal water quality in a better way. Overall, the trend of bacterial analysis covering diversified pathogen includes $E$. coli, Aeromonas, Vibrio, Pseudomonas, Salmonella, Enterococcus and total bacterial load of water samples collected from different station with sampling period revealed that during initial sampling period (October, 20), there was a higher load of various pathogenic bacteria in the water samples from different station which was reduced drastically during the later months of sampling. However, during April-May 21 sampling, the bacterial load was again showed increasing trend. This might be due to the fact that the pathogenic bacterial loads were principally dependent on the anthropogenic activity. In a recent study, at pristine environment at Gulf of Mannar (eastern part of India), similar trend of bacterial load was observed after lockdown sampling (Edward et al. 2021).

\section{Global scenario of the improved water quality due to the lockdown}

In recent past, many papers have been published worldwide showing overall improvement of water quality due to COVID-19-related lockdown and cessation of anthropogenic activities (Chakraborty et al. 2021). Robin et al. (2021) reported fewer plastic waste in the coastal water due to reduced anthropogenic activity in the Chennai coast. According to Yunus et al. (2020), the quality of lake water in China has improved as a result of COVID-19-related lockdown. Tokatlı and Varol. (2021) reported that COVID19 lockdown results in a significant decrease in heavy metals in river water, which further improved overall water 
quality. In the Philippines, it has been reported to improve the water quality due to less wastewater discharge due to closing of the restaurant, shopping, malls in the lockdown period (Pacaol. 2021). COVID-19 lockdown has also been reported to reduce the industrial activities in the Morocco which resulted in reducing the pollution in Boukhalef river (Cherif et al. 2020). Our present study supports that all these findings where considerable improvement of water quality with respect to physico-chemical as well as reduction in microbiological load were reported in the Diu coast of western India due to COVID-19-related lockdown followed by cessation of anthropogenic activities.

\section{Relationship between selected physico-chemical parameter and bacterial load in the coastal water}

As total alkalinity value formed a closed cluster with mean value of all the differential bacteria load, it is assumed that alkalinity value might have a role in the proliferation of different type of bacteria in the coastal water. Total alkalinity is a measure of the ability of a solution to resist a change in $\mathrm{pH}$ and is one of the important parameter that describe the seawater carbonate system (Rheuban et al. 2021). Since the industrial revolution, fossil fuel burning and land use changes have resulted in significant amount of carbon dioxide release and global warming (Lelieveld et al. 2019). Thus far, about one-third of this emitted $\mathrm{CO}_{2}$ has been taken up by the ocean (Sabine et al. 2004; Sabine and Feely. 2007). Although, previously, it was reported that burial of calcium carbonate have focused on pelagic open ocean production and sink within deep-sea sediments (O'Mara and Dunne. 2019). Later, it was revealed that despite representing less than $7 \%$ of the seafloor, coastal and continental shelf (neritic) environments of less than $200 \mathrm{~m}$ water depth account for more than half of all calcium carbonate accumulation in ocean sediment globally (Milliman. 1993; Milliman and Droxler. 1996; Iglesias-Rodriguez et al. 2002). In general, absorption of $\mathrm{CO}_{2}$ in the coastal water depends on many factors such as freshwater discharge, stratification, water resident time, eutrophication and upwelling (Rheuban et al. 2021). In a time series study from 2007 to 2015, it was reported that synchronous increase in total alkalinity were faster during spring-summer transition and it is a useful indicator of marine ecosystems' vulnerability to acidification pressure from various $\mathrm{CO}_{2}$ sources (Kapsenberg et al. 2017). However, total alkalinity is not typically monitored by community science organizations because of financial and analytical barriers. In general, it was reported that increase in nitrate and phosphate can cause a small decrease in total alkalinity (Wolf-Gladrow et al. 2007). Therefore, it can be assumed that total alkalinity may have an influence on the different bacterial load, eventually to the overall coastal health. In a previous study, it was reported that among different physico-chemical parameters, $\mathrm{pH}$ was the only statistically significant factor influencing the bacterial load (Salazar et al. 2020). Upto our understanding, this is the first report which can provide the approximate value of differential bacterial load in the coastal water by formulating a mathematical correlation with the common physicochemical parameter like total alkalinity.

\section{Conclusions}

A detailed study was carried out to understand the impact of 2nd phase of COVID-19 lockdown from March to May 2021, on different physico-chemical parameters by analysing monthly average data of Diu coast, India. Due to the cessation of anthropogenic activity including tourist movement, sudden changes of $\mathrm{pH}$, salinity, nitrite, nitrate and phosphate values were observed. Also there was a decreasing trends of different bacterial counts during this period (April, 2021). PCA study including all the physico-chemical and bacteriological counts showed there is single cluster of total alkalinity with all the differential bacterial count. Furthermore, mathematical correlation between total alkalinity and all other bacterial loads obtained by platting in different selective media was derived. The outcome of the work helps to predict the different bacterial load by only understanding the total alkalinity value of the study area which will have significant impact for understanding the coastal health.

Acknowledgements The authors sincerely acknowledge the Director, CSIR-CSMCRI for providing the infrastructural facilities. The authors also acknowledge Mr. Narshi R Baraiya for field sampling. The authors also sincerely acknowledge the Centralized Instrument Facility for analysis support. This manuscript has been assigned with CSIR-CSMCRI: 209/2021 registration.

Author contribution AKP: Data curation and writing-original draft. SV: Data curation. TPS: Data curation. AHS: Data curation. RBT: Review and editing. SC: Review and editing. SR: Review and editing. MAK: Visualization, review and editing. SH: Conceptualization, visualization, review, supervision and editing. All authors read and approved the manuscript.

Funding The authors sincerely thank INCOIS-MoES for the financial support to carry out the project work. TPS and AHS acknowledge INCOIS-MoES for the financial support.

Data availability Not applicable.

\section{Declarations}

Ethics approval and consent to participate The authors declare that they have no known competing financial interests or personal relationships that seem to affect the work reported in this article.

Consent for publication We do not have any individual person's data in any form. 
Competing interests The authors declare no competing interests.

\section{References}

Ahuja S, Larsen MC, Eimers JL, Patterson CL, Sengupta S, Schnoor JL (2014) Comprehensive water quality and purification. Elsevier, Amsterdam

An S, Gardner WS (2002) Dissimilatory nitrate reduction to ammonium (DNRA) as a nitrogen link, versus denitrification as a sink in a shallow estuary Laguna Madre/Baffin Bay, Texas. Marine Ecol Progress Ser 237:41-50. https://doi.org/10.3354/meps2 37041

APHA (2017) Standard methods for the examination of water and wastewater. USA, American Public Health Association/American Water Works Association/Water Environment Federation, Washington DC

Batabyal P, Mookerjee S, Einsporn MH, Lara RJ, Palit A (2014) High prevalence of toxin producing enteropathogenic Vibrios among estuarine crab in Ganges delta of West Bengal, India. Infection, Genetics and Evolution: Infect Genet Evol 26:359361. https://doi.org/10.1016/j.meegid.2014.06.001

Buck O, Niyogi DK, Townsend CR (2004) Scale-dependence of land use effects on water quality of streams in agricultural catchments. Environ Pollut 130:287-299. https://doi.org/10.1016/j. envpol.2003.10.018

Chakraborty B, Bera B, Adhikary PP, Bhattacharjee S, Roy S, Saha S, Ghosh A, Sengupta D, Shit PK (2021) Positive effects of COVID-19 lockdown on river water quality: evidence from River Damodar. India Sci Rep 11:20140. https://doi.org/10. 1038/s41598-021-99689-9

Chanchpara A, Sonpal V, Mehta G, Sahoo TP, Thorat RB, Ray S, Haldar S (2021) New normal baseline data during nationwide lock down due to Covid 19 pandemic in the world's largest ship recycling yard at Alang, India. Environ Sci Pollut Res Int 28:35051-35063. https://doi.org/10.1007/s11356-021-12885-y

Cherif EK, Vodopivec M, Mejjad N, Esteves da Silva JC, Simonovič S, Boulaassal H (2020) COVID-19 pandemic consequences on coastal water quality using WST sentinel-3 data: case of tangier. Morocco Water 12:2638. https://doi.org/10.3390/w12092638

Department of Fisheries (2019) Handbook on Fisheries Statistics, New Delhi. Handbook on FS2018.pdf. https://dof.gov.in/sites/ default/files/2020-08/

Fisheries Department, Diu (2013) The details of fishing crafts operating in Diu District. http://diu.gov.in/fishcraft.html

Edward JP, Jayanthi M, Malleshappa H, Jeyasanta KI, Laju R, Patterson J, Raj KD, Mathews G, Marimuthu A, Grimsditch G (2021) COVID-19 lockdown improved the health of coastal environment and enhanced the population of reef-fish. Marine Poll Bull 165:112124. https://doi.org/10.1016/j.marpolbul.2021.112124

Gao K, Beardall J, Häder D-P, Hall-Spencer JM, Gao G, Hutchins DA (2019) Effects of ocean acidification on marine photosynthetic organisms under the concurrent influences of warming, UV radiation, and deoxygenation. Front Mar Sci 6:322. https:// doi.org/10.3389/fmars.2019.00322

Gopal V, Shanmugasundaram A, Nithya B, Magesh N, Jayaprakash M (2018) Water quality of the Uppanar estuary, Southern India: implications on the level of dissolved nutrients and trace elements. Marine Poll Bull 130:279-286. https://doi.org/10.1016/j. marpolbul.2018.03.046

Haldar S, Mody KH, Jha B (2011) Abundance, diversity and antibiotics resistance pattern of Vibrio spp. in coral ecosystem of Kurusadai island. J Basic Microbiol 51:153-162. https://doi. org/10.1002/jobm.201000153
Haldar S, Mandal SK, Thorat RB, Goel S, Baxi KD, Parmer NP, Patel V, Basha S, Mody KH (2014) Water pollution of Sabarmati River - a Harbinger to potential disaster. Environ Monit Assess 186:2231-2242. https://doi.org/10.1007/s10661-013-3532-5

Hussain SA, Badola R (2008) Valuing mangrove ecosystem services: linking nutrient retention function of mangrove forests to enhanced agroecosystem production. Wetlands Ecol Manage 16:441-450. https://doi.org/10.1007/s11273-008-9080-z

Hussain MS, Abd-Elhamid HF, Javadi AA, Sherif MM (2019) Management of seawater intrusion in coastal aquifers: a review. Water 11:2467. https://doi.org/10.3390/w11122467

Iglesias-Rodriguez MD, Armstrong R, Feely R, Hood R, Kleypas J, Milliman JD, Sabine C, Sarmiento J (2002) Progress made in study of ocean's calcium carbonate budget. Eos, Transactions American Geophys Union 83:365-375. https://doi.org/10.1029/ 2002EO000267

Kapsenberg L, Alliouane S, Gazeau F, Mousseau L, Gattuso J-P (2017) Coastal ocean acidification and increasing total alkalinity in the northwestern Mediterranean Sea. Ocean Sci 13:411-426. https:// doi.org/10.5194/os-13-411-2017

Khatri N, Tyagi S (2015) Influences of natural and anthropogenic factors on surface and groundwater quality in rural and urban areas. Front in Life Sci 8:23-39. https://doi.org/10.1080/21553769.2014. 933716

Kumar B (2021) Spatial and temporal variations in dissolved silicate along the Indian coastal groundwaters and their export to adjacent coastal waters. Groundw Sustain Dev 14:100637. https://doi.org/ 10.1016/j.gsd.2021.100637

Lelieveld J, Klingmüller K, Pozzer A, Burnett RT, Haines A, Ramanathan V (2019) Effects of fossil fuel and total anthropogenic emission removal on public health and climate. PNAS 116:7192-7197. https://doi.org/10.1073/pnas.1819989116

Lotliker AA, Baliarsingh SK, Shesu RV, Samanta A, Naik RC, Nair TB (2021) Did the coronavirus disease 2019 lockdown phase influence coastal water quality parameters off major Indian cities and river basins? Front Mar Sci. https://doi.org/10.3389/fmars.2021. 648166

NIP Ltd (2020) Tourism Survey for Daman \& Diu, Ministry of Tourism, India. https://tourism.gov.in/sites/default/files/202004/Touri sm\%20Survey\%20Reporty\%20\%28January-\%20December\%2C\% 202014\%29\%20-\%20Daman\%20Diu.pdf.

Milliman JD (1993) Production and accumulation of calcium carbonate in the ocean: budget of a nonsteady state. Global Biogeochem Cy 7:927-957. https://doi.org/10.1029/93GB02524

Milliman J, Droxler A (1996) Neritic and pelagic carbonate sedimentation in the marine environment: ignorance is not bliss. Geolo Runds 85:496-504. https://doi.org/10.1007/BF02369004

O'Mara NA, Dunne JP (2019) Hot spots of carbon and alkalinity cycling in the coastal oceans. Scientific Rep 9:4434. https://doi. org/10.1038/s41598-019-41064-w

Pacaol NF (2021) Improvement of water quality amidst COVID-19 pandemic: a paradoxical picture. J of Pub Heal 43:e383-e384. https://doi.org/10.1093/pubmed/fdab094

Patel M, Baxi K, Dayma P, Upadhyay D, Parmar N, Kundu S, Haldar S, Mody KH, Jha B (2014) Assessment of ground water quality with respect to bacteriological contamination in Bhavnagar, Gujarat, India. Clean-Soil, Air, Water 42:1351-1362. https://doi.org/10. 1002/clen.201300461

Peters NE, Meybeck M (2000) Water quality degradation effects on freshwater availability: impacts of human activities. Water Int 25:185-193. https://doi.org/10.1080/02508060008686817

Rheuban J, Gassett P, McCorkle D, Hunt C, Liebman M, Bastidas C, O'Brien-Clayton K, Pimenta A, Silva E, Vlahos P (2021) Synoptic assessment of coastal total alkalinity through community science. Environ Res Lett 16:024009. https://doi.org/10.4211/hs. 4364cffedc7e49d49255eef5f8e83148 
Robin R, Purvaja R, Ganguly D, Hariharan G, Paneerselvam A, Sundari R, Karthik R, Neethu C, Saravanakumar C, Semanti P (2021) COVID-19 restrictions and their influences on ambient air, surface water and plastic waste in a coastal megacity, Chennai. India Marine Pollut Bull 171:112739. https://doi.org/10.1016/j.marpo lbul.2021.112739

Sabine CL, Feely RA, Gruber N, Key RM, Lee K, Bullister JL, Wanninkhof R, Wong CL, Wallace DWR, Tilbrook B, Millero FJ, Peng T-H, Kozyr A, Ono T, Rios AF (2004) The oceanic sink for anthropogenic $\mathrm{CO}_{2}$. Science 305(5682):367-371

Sabine CL, Feely RA (2007) The oceanic sink for carbon dioxide. D. Reay, N. Hewitt, J. Grace, and K. Smith (eds.), In Greenhouse Gas Sinks., CABI Publishing, Oxfordshire, UK, 31-49.

Salazar NR, Aguirre C, Soto J, Salinas P, Salinas C, Prieto H, Paneque M (2020) Physicochemical parameters affecting the distribution and diversity of the water column microbial community in the high-altitude Andean lake system of La Brava and La Punta. Microorganisms 8:1181. https://doi.org/10.3390/microorgan isms8081181

Shinde AH, Raval IH, Haldar S (2020) SXT int harboring bacteria as effective indicators to determine high-risk reservoirs of multiple antibiotic resistance in different aquatic environments of western coast of Gujarat. India Ecol Indic 113:106143. https://doi.org/10. 1016/j.ecolind.2020.106143

Tokatl C, Varol M (2021) Impact of the COVID-19 lockdown period on surface water quality in the Meriç-Ergene River Basin. Northwest Turkey Environ Res 197:111051. https://doi.org/10.1016/j. envres.2021.111051

Uddin MJ, Jeong Y (2021) Urban river pollution in Bangladesh during last 40 years: potential public health and ecological risk, present policy, and future prospects toward smart water management. Heliyon 7:e06107. https://doi.org/10.1016/j.heliyon.2021.e06107
Verlecar XN, Desai SR, Sarkar A, Dalal S (2006) Biological indicators in relation to coastal pollution along Karnataka coast, India. Water Res 40:3304-3312. https://doi.org/10.1016/j.watres.2006.06.022

Wolf-Gladrow DA, Zeebe RE, Klaas C, Körtzinger A, Dickson AG (2007) Total alkalinity: the explicit conservative expression and its application to biogeochemical processes. Mar Chem 106:287300. https://doi.org/10.1016/j.marchem.2007.01.006

Yunus AP, Masago Y, Hijioka Y (2020) COVID-19 and surface water quality: improved lake water quality during the lockdown. Sci Tot Environ 731:139012. https://doi.org/10.1016/j.scitotenv.2020. 139012

Zakem EJ, Al-Haj A, Church MJ, van Dijken GL, Dutkiewicz S, Foster SQ, Fulweiler RW, Mills MM, Follows MJ (2018) Ecological control of nitrite in the upper ocean. Nat Commun 9:1206. https:// doi.org/10.1038/s41467-018-03553-w

Zhang Q, Li Z, Zeng G, Li J, Fang Y, Yuan Q, Wang Y, Ye F (2009) Assessment of surface water quality using multivariate statistical techniques in red soil hilly region: a case study of Xiangjiang watershed, China. Environ Monit Assess 152:123-131. https:// doi.org/10.1007/s10661-008-0301-y

Zingde M, Govindan K (2000) Health status of the coastal waters of Mumbai and regions around. http://drs.nio.org/drs/handle/2264/ 1635

Publisher's Note Springer Nature remains neutral with regard to jurisdictional claims in published maps and institutional affiliations. 